\title{
Epidemiology of paediatric gastrointestinal colonisation by extended spectrum cephalosporin-resistant Escherichia coli and Klebsiella pneumoniae isolates in north-west Cambodia
}

\author{
J. J. van Aartsen ${ }^{1,2^{*}}$ (D, C. E. Moore ${ }^{1}$, C. M. Parry ${ }^{3}$, P. Turner ${ }^{4,5}$, N. Phot ${ }^{6}$, S. Mao ${ }^{6}$, K. Suy ${ }^{6}$, T. Davies ${ }^{1}$, A. Giess ${ }^{1}$, \\ A. E. Sheppard ${ }^{1}$, T. E. A. Peto ${ }^{1}$, N. P. J. Day ${ }^{5,7}$, D. W. Crook ${ }^{1}$, A. S. Walker ${ }^{1}$ and N. Stoesser ${ }^{1,8^{*}}$
}

\begin{abstract}
Background: Extended-spectrum cephalosporin resistance (ESC-R) in Escherichia coli and Klebsiella pneumoniae is a healthcare threat; high gastrointestinal carriage rates are reported from South-east Asia. Colonisation prevalence data in Cambodia are lacking. The aim of this study was to determine gastrointestinal colonisation prevalence of ESC-resistant E. coli (ESC-R-EC) and K. pneumoniae (ESC-R-KP) in Cambodian children/adolescents and associated socio-demographic risk factors; and to characterise relevant resistance genes, their genetic contexts, and the genetic relatedness of ESC-R strains using whole genome sequencing (WGS).

Results: Faeces and questionnaire data were obtained from individuals $<16$ years in north-western Cambodia, 2012. WGS of cultured ESC-R-EC/KP was performed (Illumina). Maximum likelihood phylogenies were used to characterise relatedness of isolates; ESC-R-associated resistance genes and their genetic contexts were identified from de novo assemblies using BLASTn and automated/manual annotation. 82/148 (55\%) of children/adolescents were ESC-R-EC/KP colonised; 12/148 (8\%) were co-colonised with both species. Independent risk factors for colonisation were hospitalisation (OR: 3.12, 95\% Cl [1.52-6.38]) and intestinal parasites (OR: 3.11 [1.29-7.51]); school attendance conferred decreased risk (OR: 0.44 [0.21-0.92]. ESC-R strains were diverse; the commonest ESC-R mechanisms were blactX-M 1 and 9 sub-family variants. Structures flanking these genes were highly variable, and for

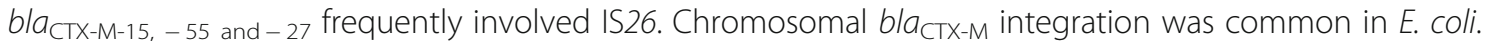

Conclusions: Gastrointestinal ESC-R-EC/KP colonisation is widespread in Cambodian children/adolescents; hospital admission and intestinal parasites are independent risk factors. The genetic contexts of bla $a_{\text {CTX-M }}$ are highly mosaic, consistent with rapid horizontal exchange. Chromosomal integration of bla ${ }_{\mathrm{CTX}-\mathrm{M}}$ may result in stable propagation in these community-associated pathogens.
\end{abstract}

Keywords: Paediatric, ESBL, Carriage, Cambodia

\footnotetext{
* Correspondence: jjvanaartsen@outlook.com; nicole.stoesser@ndm.ox.ac.uk

${ }^{1}$ Nuffield Department of Clinical Medicine and the National Institute for Health Research Oxford Biomedical Research Centre (NIHR-OxBRC), University of Oxford, Oxford, UK

Full list of author information is available at the end of the article
}

(c) The Author(s). 2019 Open Access This article is distributed under the terms of the Creative Commons Attribution 4.0 International License (http://creativecommons.org/licenses/by/4.0/), which permits unrestricted use, distribution, and reproduction in any medium, provided you give appropriate credit to the original author(s) and the source, provide a link to the Creative Commons license, and indicate if changes were made. The Creative Commons Public Domain Dedication waiver (http://creativecommons.org/publicdomain/zero/1.0/) applies to the data made available in this article, unless otherwise stated. 


\section{Background}

Escherichia coli and Klebsiella pneumoniae are two bacterial pathogens of the Enterobacteriaceae family that can cause a wide spectrum of clinical disease, ranging from cystitis and intra-abdominal abscesses to sepsis. Both species also asymptomatically colonise the gastrointestinal tract, a reservoir that assists in the acquisition and spread of antimicrobial resistance (AMR) [1, 2]. The increasing prevalence of AMR worldwide is reducing the efficacy of our limited armamentarium of empirical broad-spectrum antibiotics, such as extended-spectrum cephalosporins (ESCs), resulting in increased healthcare costs and mortality [3-5].

Recent reports from South-east Asia show substantial variation between country and cohort in gastrointestinal colonisation by Enterobacteriaceae possessing Ambler class A extended spectrum beta-lactamases (ESBLs) and/or class C AmpC enzymes, which can hydrolyse third and fourth generation cephalosporins. In the Lao People's Democratic Republic, for example, $23 \%$ of pre-school children carried these strains, in contrast to a much higher prevalence of $65.7 \%$ in a rural Thai adult population [6-8]. Data describing the prevalence and mechanisms of antibiotic resistance in Cambodia are limited to only a few studies. Vlieghe and colleagues found $49.7 \%$ of Enterobacteriaceae from blood cultures in Phnom Penh from 2007 to 2010 were cefotaxime-resistant, mostly due to CTX-M-15 and CTX-M-14 enzymes [9]. Studies from 2004/5 and 2007-2011 identified ESC resistance in 36-44\% of urinary tract infection isolates [10, 11]. Recent data from a Cambodian reference laboratory suggests that the prevalence of ESBL resistance amongst Enterobacteriaceae isolated from hospitalised and community-based patients increased from $23.8 \%$ in 2012 to $38.4 \%$ in 2015 [12]. The gastrointestinal colonisation prevalence of ESCresistant (ESC-R) E. coli and K. pneumoniae in Cambodia has previously only been investigated in hospitalised neonates [13], where on initial admission $21 \%$ were colonised with ESC-R E. coli (ESC-R-EC) and 33\% with ESC-R K. pneumoniae (ESC-R-KP), increasing to 34 and $42 \%$ respectively on repeat admissions. Our study aimed to expand on this work by: (i) estimating the prevalence of gastrointestinal colonisation with ESC-R-EC and ESC-R-KP in Cambodian children and adolescents, and the molecular mechanisms responsible; (ii) investigating socio-demographic risk factors for ESC-R colonisation; (iii) determining genetic relatedness of ESC-R strains.

\section{Results}

\section{Sampling, culture and basic demographics}

In total, 196 faecal samples were obtained from a consecutive subset of children/adolescents enrolled in an intestinal parasite prevalence study. 48 samples were excluded from this study because of: (i) lack of specific consent for wider use of the faecal samples beyond the faecal parasite survey ( $n=36)$; (ii) no epidemiological data records $(n=1)$; (iii) no $(n=3)$ or poor $(n=5)$ growth on culture; or (iv) replicate samples for the same patient $(n=3)$, leaving 148 samples/individuals for analysis.

Overall, 184 distinct colony types grew within the cefpodoxime inhibition zones; 141 were pink (presumed E. coli) and 43 were blue (presumed Klebsiella spp., Enterobacter spp. or Citrobacter spp.). All pink colonies but only 22/43 (54\%) blue colonies were confirmed as phenotypically ESC-R using BSAC methods. All 163 confirmed ESC-R isolates were sequenced; two failed and were excluded from further analysis. Of the 161 sequences, in silico species identification confirmed 135 (84\%) isolates were E. coli, 18 (11\%) K. pneumoniae, and 8 (5\%) Enterobacter spp. 38 $E$. coli isolates and one $K$. pneumoniae isolate were genetically sufficiently closely related to another isolate obtained from the same patient sample to be considered as the same strain (defined as $\leq 5$ chromosomal SNVs); these were also excluded leaving 122 isolates for analysis. None of the 148 faecal samples yielded imipenem resistant colonies.

Participants were median 4.2 years old (interquartile range: 1.1-8.8) at sample collection; 70/148 (47\%) were male. 70/ 147 (48\%; 1 missing) were inpatients at sample collection. Although most were from Siem Reap province (99/148 [67\%]), the hospital catchment is such that the remainder were recruited from 10 other provinces. 16/148 (11\%) were clinically malnourished, and 23/148 (16\%) had $\geq 1$ underlying chronic medical condition including $\operatorname{HIV}(n=5)$, haematological disease $(n=3)$, congenital cardiac disease $(n=5)$, tuberculosis $(n=4)$, and asthma $(n=2)$ (Table 1$)$.

\section{Prevalence of and risk factors for colonisation with ESC-R EC and/or ESC-R-KP}

A total of 114 confirmed ESC-R-EC $(n=97)$ and ESC-R-KP $(n=17)$ remained in the analysis and were carried by $82 /$ 148 participants, giving a combined ESC-R-EC/KP prevalence of 55\% (95\% CI: 47-64\%); 53\% for ESC-R EC (79/148 patients; 95\% CI: 45-62\%) and 10\% for ESC-R KP (15/148 patients; 95\% CI: 6-16\%). Co-colonisation with both ESCR-EC and ESC-R-KP was observed in 12/82 (15\%). Independent risk factors for ESC-R-EC/KP colonisation included being a current inpatient $(\mathrm{OR}=3.64 ; 95 \% \mathrm{CI}$ $[1.71-7.74), p=0.001)$ and the presence of faecal parasites $(\mathrm{OR}=3.96$ [1.55-10.12], $p=0.004)$. ESC-R-EC/KP colonisation was lower in males $(\mathrm{OR}=0.39$ [0.18-0.84], $p=0.015)$ and in those attending school ( $\mathrm{OR}=0.39$ [0.18-0.83], $p=0.015$ ) (Table 1).

\section{Sequence type, ambler class and genetic mechanisms of ESC-R}

The 97 ESC-R-EC isolates came from 33 known and 6 novel STs (Fig. 1, for details see Additional file 1: Table S1). 
Table 1 Clinical and epidemiological details of all 148 participants, also categorised by presence/absence of gastrointestinal colonisation with ESC-resistant E. coli and/or K. pneumoniae, and multivariable logistic regression outcomes

\begin{tabular}{|c|c|c|c|c|c|c|c|}
\hline & \multirow{2}{*}{ 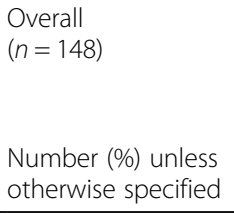 } & \multirow{2}{*}{$\begin{array}{l}\text { ESC-R E. coli/K. } \\
\text { pneumoniae colonised } \\
(n=82 ; 55 \%) \\
n(\%)\end{array}$} & \multirow{2}{*}{$\begin{array}{l}\text { ESC-R E. coli/K. } \\
\text { pneumoniae } \\
\text { non-colonised } \\
(n=66 ; 45 \%) \\
n(\%)\end{array}$} & \multicolumn{2}{|c|}{$\begin{array}{l}\text { Univariable } \\
\text { logistic regression } \\
\text { for ESC-R carriage }\end{array}$} & \multicolumn{2}{|c|}{$\begin{array}{l}\text { Multivariable logistic } \\
\text { regression for ESC-R } \\
\text { carriage }^{d}\end{array}$} \\
\hline & & & & $\mathrm{OR}[95 \% \mathrm{Cl}]$ & $p$ & OR $[95 \% \mathrm{Cl}]$ & $p$ \\
\hline Median age [IQR], years & $4.24[1.10-8.82]$ & $3.07[0.97-7.21]$ & $6.23[1.32-9.23]$ & $1.00[1.00-1.00]$ & 0.712 & & \\
\hline Male & $70(47)$ & $35(43)$ & $35(53)$ & $0.66[0.34-1.27]$ & 0.211 & $0.39[0.18-0.84]$ & 0.015 \\
\hline Inpatient ${ }^{\mathrm{a}}$ & $70(48)$ & $49(60)$ & $20(32)$ & $3.28[1.66-6.50]$ & 0.001 & $3.64[1.71-7.74]$ & 0.001 \\
\hline \multicolumn{8}{|l|}{ Province } \\
\hline Siem Reap & $99(67)$ & $51(62)$ & $48(72)$ & 1 & & & \\
\hline Other (versus Siem Reap) & $49(33)$ & $31(38)$ & $18(28)$ & $1.06[0.72-1.58]$ & 0.716 & & \\
\hline Malnutrition & $16(11)$ & $12(15)$ & $4(6)$ & $2.66[0.81-8.67]$ & 0.105 & & \\
\hline Co-morbidities $^{f}$ & $25(17)$ & $19(23)$ & $6(9)$ & $3.01[1.13-8.06]$ & 0.028 & & \\
\hline Diarrhoea present ${ }^{\mathrm{b}}$ & $70(48)$ & $44(54)$ & $26(40)$ & $1.78[0.92-3.46]$ & 0.086 & & \\
\hline \multicolumn{8}{|l|}{ Water sources } \\
\hline Well & $123(83)$ & $64(78)$ & $59(89)$ & $0.42[0.16-1.08]$ & 0.073 & & \\
\hline Bottled & $17(11)$ & $13(16)$ & $4(6)$ & $2.92[0.90-9.43]$ & 0.073 & & \\
\hline River & $5(3)$ & $3(4)$ & $2(3)$ & $1.22[0.20-7.49]$ & 0.834 & & \\
\hline Rain & $8(5)$ & $5(6)$ & $3(5)$ & $1.36[0.31-5.93]$ & 0.680 & & \\
\hline School attendance & $71(48)$ & $32(39)$ & $39(59)$ & $0.44[0.23-0.86]$ & 0.016 & $0.39[0.18-0.83]$ & 0.015 \\
\hline All animals & $119(80)$ & $65(79)$ & $54(82)$ & & & & \\
\hline Domestic animals & $113(76)$ & $61(74)$ & $50(79)$ & $0.78[0.36-1.69]$ & 0.532 & & \\
\hline Cat & $51(34)$ & $32(39)$ & $19(29)$ & $1.58[0.79-3.17]$ & 0.194 & & \\
\hline Dog & $100(68)$ & $57(70)$ & $43(65)$ & $1.22[0.61-2.43]$ & 0.573 & & \\
\hline Birds & $24(16)$ & $12(15)$ & $12(18)$ & $0.77[0.32-1.85]$ & 0.561 & & \\
\hline Livestock/food animals & $89(60)$ & $54(66)$ & $35(53)$ & $1.71[0.88-3.32$ & 0.114 & & \\
\hline Water buffalo & $4(3)$ & $3(4)$ & $1(1)$ & $2.47[0.25-24.3]$ & 0.439 & & \\
\hline Chickens & $80(54)$ & $49(60)$ & $31(47)$ & $1.67[0.87-3.23]$ & 0.122 & & \\
\hline Pigs & $23(16)$ & $14(17)$ & $9(14)$ & $1.30[0.53-3.23]$ & 0.567 & & \\
\hline Ducks & $2(1)$ & $2(2)$ & 0 & 1 (omitted) & & & \\
\hline Cattle & $24(16)$ & $15(18)$ & $9(14)$ & $1.42[0.58-3.48]$ & 0.446 & & \\
\hline Use of toilet for defecation & $88(59)$ & $45(54)$ & $42(65)$ & $0.65[0.33-1.27]$ & 0.207 & & \\
\hline \multicolumn{8}{|l|}{ Use of soap ${ }^{c}$} \\
\hline Never & $34(23)$ & $18(23)$ & $16(25)$ & 1 & & & \\
\hline Some use (versus Never) & $111(77)$ & $62(76)$ & $49(75)$ & $1.12[0.52-2.43]$ & 0.765 & & \\
\hline Presence of intestinal parasites & $36(24)$ & 25 (30.49) & $11(17.19)$ & $2.19[0.99-4.88]$ & 0.054 & $3.96[1.55-10.12]$ & 0.004 \\
\hline
\end{tabular}

${ }^{a}$ missing one datapoint $(n=147)$

${ }^{\mathrm{b}}$ missing two datapoints $(n=146)$

cmissing three datapoints $(n=145)$

${ }^{\mathrm{d} B a c k w a r d s}$ elimination performed using 144 cases for which complete information available, on all predictors, using exit $p \leq 0.1$. Final model then incorporated 147 cases for which complete information available on included predictors (gender, inpatient status, presence of intestinal parasites and school attendance) e"Other province" category includes: Banteay Meanchey $(n=21)$, Oddar Meanchey (8), Kampong Thom (6), Battambang (5), Preah Vihear (3), Kampong Cham (2), Kampong Chhang (1), Pursat (1), Other (2)

fIncludes: HIV ( $n=5)$, blood dyscrasia (3), Down's syndrome (2), congenital heart disease (6), tuberculosis (4), asthma (2), other (8); five individuals had multiple co-morbidities

$p$-values $<0.05$ in bold 


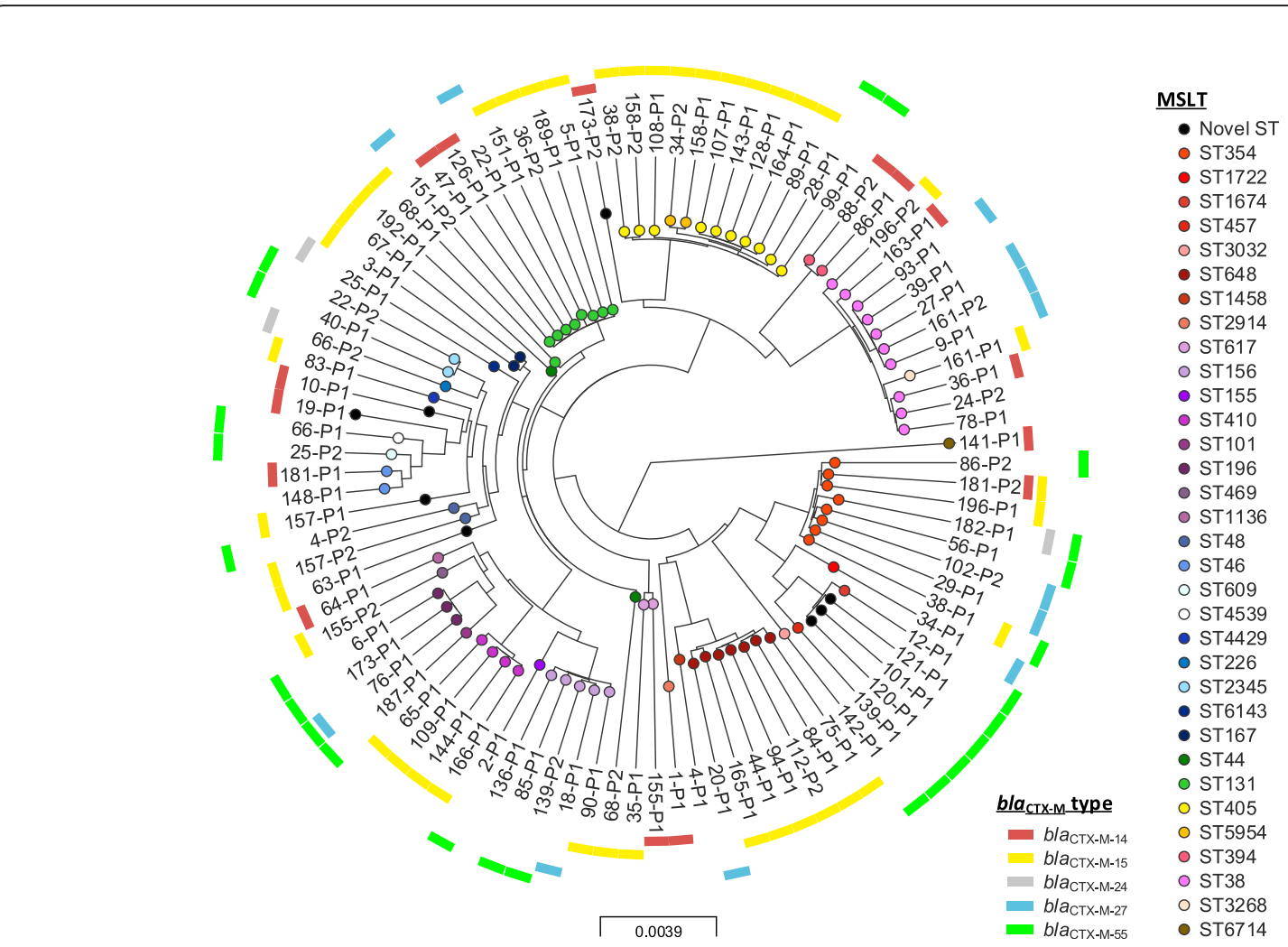

Fig. 1 Phylogeny of study Escherichia coli isolates. Interactive map of geographic locations and genetic attributes can be visualised at: https://microreact.org/project/By8bf5ajg

$22 \%(17 / 79)$ of patients were colonised by at least two different ESC-R-EC STs, although this may underestimate diversity as only a small number of colonies $(\leq 3)$ were sampled per patient [14]. The 17 ESC-R-KP strains came from 11 known and 3 novel STs $(n=4$ isolates) (Fig. 2, Additional file 1: Table S2). Two patients were colonised by two different ESC-R K. pneumoniae STs (2/15, 13\%).

In total, $77 \%(88 / 114)$ and $23 \%(26 / 114)$ of isolates displayed Ambler class A or C phenotypes, respectively
(Table 2). Neither species were associated with Ambler class A (76\% [74/97] versus 82\% [14/17]) or class C (24\% [23/97] versus $18 \%$ [3/17]; Fishers exact test; $p=0.759$ ). In all class $\mathrm{A}$ isolates the phenotype could be explained by the presence of one $(84 / 88,95 \%)$ or two $(4 / 88,5 \%) b^{2} a_{\mathrm{CTX}-\mathrm{M}}$ genes; bla $a_{\mathrm{SHV}}(12 / 88,14 \%)$ and bla $a_{\mathrm{VEB}}(1 / 88,1 \%)$ occurred less commonly. Class $\mathrm{C}$ gene families were only identified in $38 \%(10 / 26)$ of phenotypically class $C$ isolates: specifically bla $_{\mathrm{CMY}-2}(8 / 26,31 \%)$ or bla $a_{\mathrm{DHA}}(2 / 26,8 \%)$. In

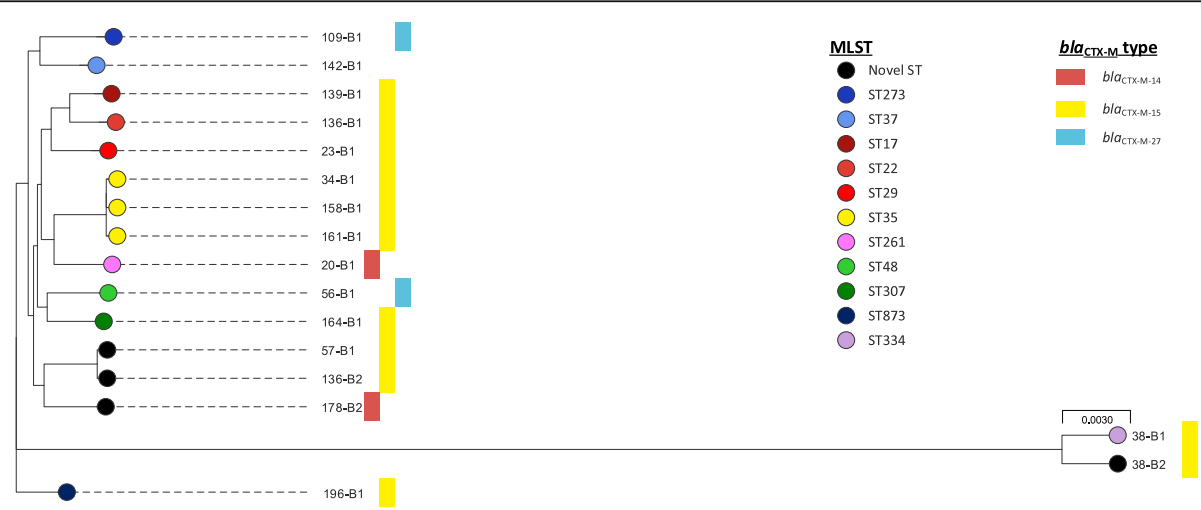

Fig. 2 Phylogeny of study Klebsiella pneumoniae isolates. Interactive map of geographic locations and genetic attributes can be visualised at: https://microreact.org/project/Hy_yQcaog 
Table 2 Summary of Ambler Class A and C phenotypes and genotypes in ESC-resistant E. coli and K. pneumoniae isolates

\begin{tabular}{|c|c|c|c|c|c|c|c|}
\hline & \multicolumn{7}{|c|}{ Amber Class Phenotype } \\
\hline & \multicolumn{2}{|c|}{ E. coli $(n=97)$} & \multicolumn{2}{|c|}{ K. pneumoniae $(n=17)$} & \multicolumn{2}{|c|}{ Both species $(n=114)$} & \multirow{2}{*}{$\begin{array}{l}\text { Total } \\
(n=114)\end{array}$} \\
\hline & $\mathrm{A}(n=74)$ & $C(n=23)$ & $\mathrm{A}(n=14)$ & $C(n=3)$ & $\mathrm{A}(n=88)$ & $C(n=26)$ & \\
\hline \multicolumn{8}{|l|}{ Ambler Class A genes } \\
\hline bla $_{\text {CTX-M }}$ positive ${ }^{a}$ & 73 (99\%) & $18(78 \%)$ & $14(100 \%)$ & $2(67 \%)$ & 87 (99\%) & 20 (77\%) & $107(94 \%)$ \\
\hline CTX-M-14 & 14 & 1 & 2 & 0 & 16 & 1 & 17 \\
\hline CTX-M-15 & 28 & 13 & 12 & 0 & 40 & 13 & 53 \\
\hline CTX-M-24 & 2 & 1 & 0 & 0 & 2 & 1 & 3 \\
\hline CTX-M-27 & 12 & 0 & 0 & 2 & 12 & 2 & 14 \\
\hline CTX-M-55 & 20 & 4 & 0 & 0 & 20 & 4 & 24 \\
\hline Total & 76 & 19 & 14 & 2 & 90 & 21 & 111 \\
\hline bla $_{\mathrm{SHV}}$ positive & $0(0 \%)$ & $0(0 \%)$ & $12(86 \%)$ & $2(67 \%)$ & $12(14 \%)$ & $2(8 \%)$ & $14(12 \%)$ \\
\hline SHV-1/1-like ${ }^{c}$ & 0 & 0 & 2 & 1 & 2 & 1 & 3 \\
\hline SHV-11/11-like & 0 & 0 & 2 & 1 & 2 & 1 & 3 \\
\hline $\mathrm{SHV}-27^{\mathrm{b}}$ & 0 & 0 & 1 & 0 & 1 & 0 & 1 \\
\hline$S H V-28^{b}$ & 0 & 0 & 1 & 0 & 1 & 0 & 1 \\
\hline SHV-33 & 0 & 0 & 3 & 0 & 3 & 0 & 3 \\
\hline SHV- $83^{c}$ & 0 & 0 & 1 & 0 & 1 & 0 & 1 \\
\hline SHV-99/99-like & 0 & 0 & 1 & 0 & 1 & 0 & 1 \\
\hline SHV-142 & 0 & 0 & 1 & 0 & 1 & 0 & 1 \\
\hline Total & 0 & 0 & 12 & 2 & 12 & 2 & 14 \\
\hline bla $_{V E B}$ positive & $1(1 \%)$ & $0(0 \%)$ & $0(0 \%)$ & $0(0 \%)$ & $1(1 \%)$ & $0(0 \%)$ & $1(1 \%)$ \\
\hline None identified & 0 & $5(22 \%)$ & $0(0 \%)$ & $0(0 \%)$ & $0(0 \%)$ & $0(0 \%)$ & $5(4 \%)$ \\
\hline \multicolumn{8}{|l|}{ Ambler Class $C$ genes } \\
\hline bla $a_{\mathrm{CMY}-2}$ positive & $0(0 \%)$ & $8(35 \%)$ & $0(0 \%)$ & $0(0 \%)$ & $0(0 \%)$ & $8(31 \%)$ & $8(31 \%)$ \\
\hline$b / a_{\mathrm{DHA}}$ positive & $0(0 \%)$ & $1(4 \%)$ & $0(0 \%)$ & 1 (33\%) & $0(0 \%)$ & $2(8 \%)$ & $2(8 \%)$ \\
\hline bla $a_{\text {Act-like }}$ positive & $0(0 \%)$ & $0(0 \%)$ & $0(0 \%)$ & $0(0 \%)$ & $0(0 \%)$ & $0(0 \%)$ & $0(0 \%)$ \\
\hline None identified & $0(0 \%)$ & $14(61 \%)$ & $0(0 \%)$ & $2(67 \%)$ & $0(0 \%)$ & 16 (62\%) & $16(62 \%)$ \\
\hline
\end{tabular}

Isolates with two separate bla $a_{\text {CTX-M }}$ alleles were identified in $4 \%$ of isolates $(4 / 114)$

${ }^{b}$ ESBL

cnot ESBL

dUnknown beta-lactamase phenotype

the remaining 16 isolates, the genetic basis for the class $\mathrm{C}$ phenotype was unclear; of note, however, $\operatorname{ampC}$ promoter mutations were not assessed.

One hundred eleven $b l a_{\text {СтХ-M }}$ genes were found in 94\% (107/114) of ESC-R-EC/KP, with two separate alleles identified in $4 \%$ of isolates (4/114). The most frequently identified allele was $b l a_{\mathrm{CTX}-\mathrm{M}-15}(53 / 111,48 \%)$, followed by: bla $_{\text {CTX-M-55 }}(24 / 111,22 \%)$, bla $(17 / 111,15 \%)$, bla $a_{\mathrm{CTX}-\mathrm{M}-27}(14 / 111,13 \%)$ and $b l a_{\mathrm{CTX}}$ M-24 $(3 / 111,3 \%)$. Two different $b a_{\text {CTX-M }}$ alleles were found in 21\% (18/82) of individuals carrying ESC-R-EC/KP.

All 15 identified $b l a_{\mathrm{SHV}}$ genes were found only in ESC-R-KP. Of these, 3/15 (20\%) are likely to confer ESC-R: bla $a_{\mathrm{SHV}-27-\text { like }}(1 / 15,7 \%), 1 / 15$ bla $_{\mathrm{SHV}-28}(1 / 15,7 \%)$, bla $_{\mathrm{S}-}$ HV-99-like (1/15, 7\%); the remaining possess either narrow-spectrum beta-lactamase activity (11/15, 73\%: 3/15 bla $_{\text {SHV-1/ SHV-1-like, }} 20 \%$; 4/15 bla $a_{\text {SHV-11/ SHV-11-like, }} 27 \%$; 3/ 15 bla $_{\mathrm{SHV}-33}, 20.0 \%$; and $1 / 15$ bla $\left._{\mathrm{SHV}-83}, 7 \%\right)$ or their beta-lactamase phenotype is unknown (1/15, 7\%: $1 / 15$ bla $\left.a_{\mathrm{SHV}-142}, 7 \%\right)$. All bla $a_{\mathrm{SHV}-\mathrm{positive}}$ ESC-R-KP possessed other genes that could explain their ESC-R phenotype: bla $a_{\mathrm{CTX}-\mathrm{M}-14}(2 / 15,13 \%)$, bla $a_{\mathrm{CTX}-\mathrm{M}-15}(10 / 15,67 \%)$, bla $a_{\mathrm{CTX}-\mathrm{M}-27}(2 / 15,13 \%)$, or bla $a_{\mathrm{DHA}}(1 / 15,7 \%)$. The study population carriage prevalence of common ESC-R conferring genetic mechanisms encoded by ESC-R-EC/KP was therefore: $53 \%$ bla $_{\mathrm{CTX}-\mathrm{M}}(78 / 148), 2 \%$ bla $_{\mathrm{SHV}}(3 / 148)$, $1 \%$ bla $_{\mathrm{VEB}}(1 / 148), 5 \%$ bla $_{\mathrm{CMY}-2}(8 / 148), 1 \%$ bla $_{\mathrm{DHA}}$ (2/148). Two individuals (1\%) carried isolates with $b l a_{\text {OXA-48 }}$ (one K. pneumoniae ST48 [56B1] and one E. coli ST648 [94P1]); no other carbapenem resistance mechanisms were identified. Both isolates were resistant to ertapenem with a minimum inhibitory concentration (MIC) of $>1 \mu \mathrm{g} / \mathrm{ml}$ ); 56B1 
had intermediate resistance to imipenem (MIC $4 \mu \mathrm{g} / \mathrm{ml}$ ) and meropenem (MIC $8 \mu \mathrm{g} / \mathrm{ml}$ ), whilst 94P1 was sensitive to both with MICs of $1 \mu \mathrm{g} / \mathrm{ml}$ and $0.25 \mu \mathrm{g} / \mathrm{ml}$, respectively.

\section{Genetic context of bla $a_{\mathrm{CTX}-\mathrm{M}}$}

For the $41 E$. coli harbouring $b l a_{\mathrm{CTX}-\mathrm{M}-15}$, it was chromosomally located in five cases (12\%), and likely in plasmid contexts in two; in the remaining cases it was not possible to determine wider chromosomal/ plasmid location (Table 3). One isolate (38P1) harboured short contigs containing truncated $b l a_{\mathrm{CTX}-\mathrm{M}-15}$, leaving 40 cases in which to evaluate the immediate flanking contexts surrounding the $b l a_{\text {СтX-M }}$ gene. All contained ISEcp1 upstream of bla $_{\mathrm{CTX}-\mathrm{M}-15}$, but with considerable evidence of additional mobilisation events/mosaicism (Table 3). In particular, ISEcp1 was truncated by IS26 at 24, 497, 524, $1067,1173,1421$, or $1489 \mathrm{bp}$ in 13 isolates, consistent with at least seven IS26-associated insertion events within

Table 3 Summary of genetic contexts of bla ${ }_{\mathrm{CTX}-\mathrm{M}}$ in ESC-resistant E. coli and K. pneumoniae

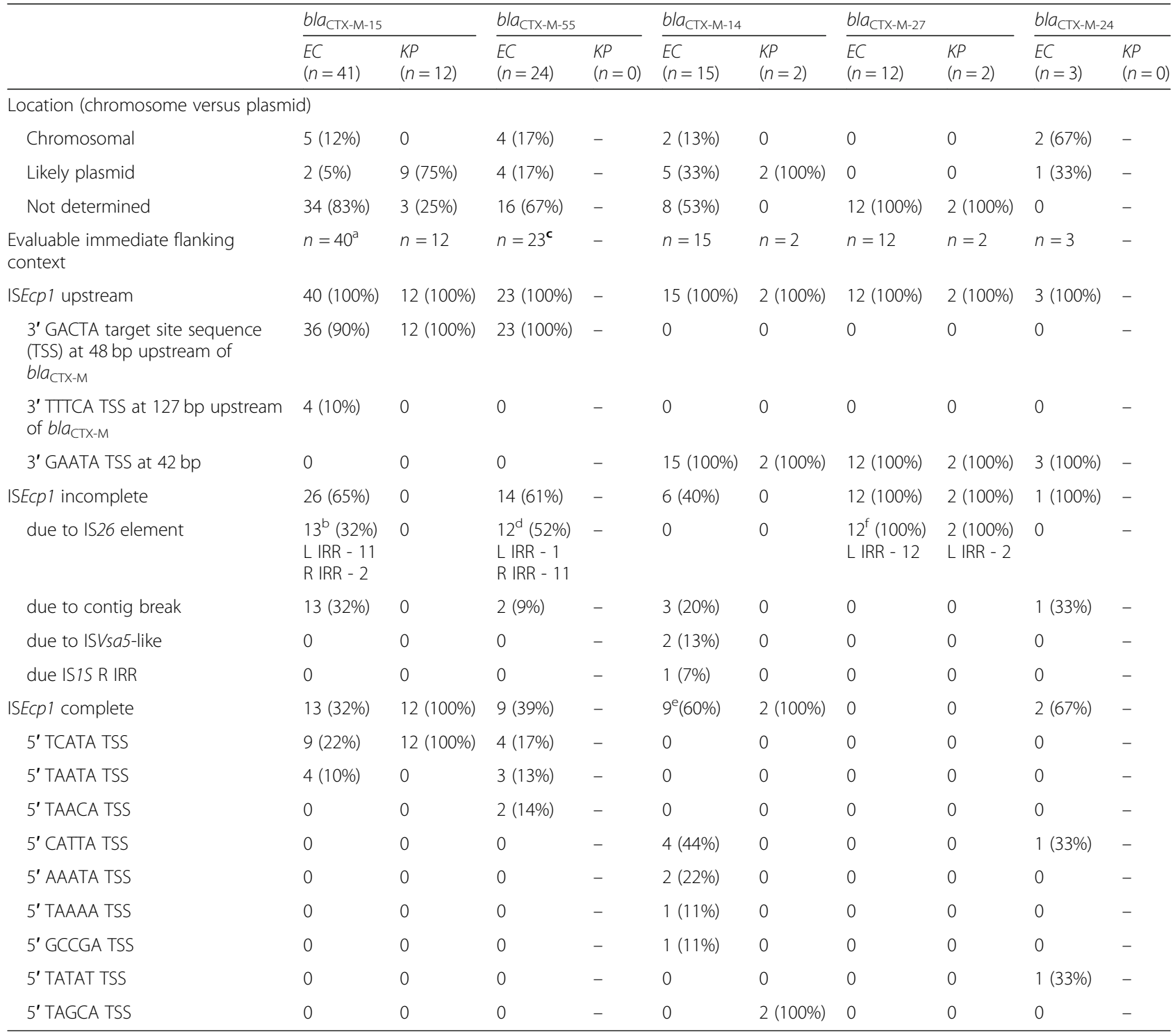

$E C=E$. coli, $K P=K$. pneumoniae

a excluding one isolate with short contigs harbouring truncated $b l a_{\mathrm{CTX}-\mathrm{M}-15}$

bISEcp1 truncated at $24,497,524,1067,1173,1421$, or 1489 bp

cexcluding one isolate with short contig harbouring truncated $b / a_{\mathrm{CTX}-\mathrm{M}-55}$

'ISEcp1 truncated at 267, 309 or $497 \mathrm{bp}$

'For one only $1 \mathrm{bp}$ of 5 ' TSS evaluable

fISEcp 1 truncated at 149, 192, 208 and 388 bp

TSS = target site sequence

$\mathrm{L} I \mathrm{RR}=$ left inverted repeat region

$\mathrm{R} I \mathrm{RR}=$ left inverted repeat region 
ISEcp1 (Fig. 3). Another 13 ISEcp1 elements were truncated by contig breaks, without any specific associated genetic signatures, although contig breaks are frequently due to repeat structures and may therefore have represented additional disruption events. One isolate had an intact ISEcp1 element, without any wider flanking upstream context. The 13 cases with an intact ISEcp 1 were consistently flanked by variable lengths of Tn2, which was truncated by an IS26 right IRR in $2 / 7$ evaluable cases (and by an unknown sequence in the other 5/7). Two isolates had a complete $\operatorname{Tn} 2$ structure interrupted by ISEcp1-bla $a_{\mathrm{CTX}-\mathrm{M}-15}$ (TCTCA-TCTCA and

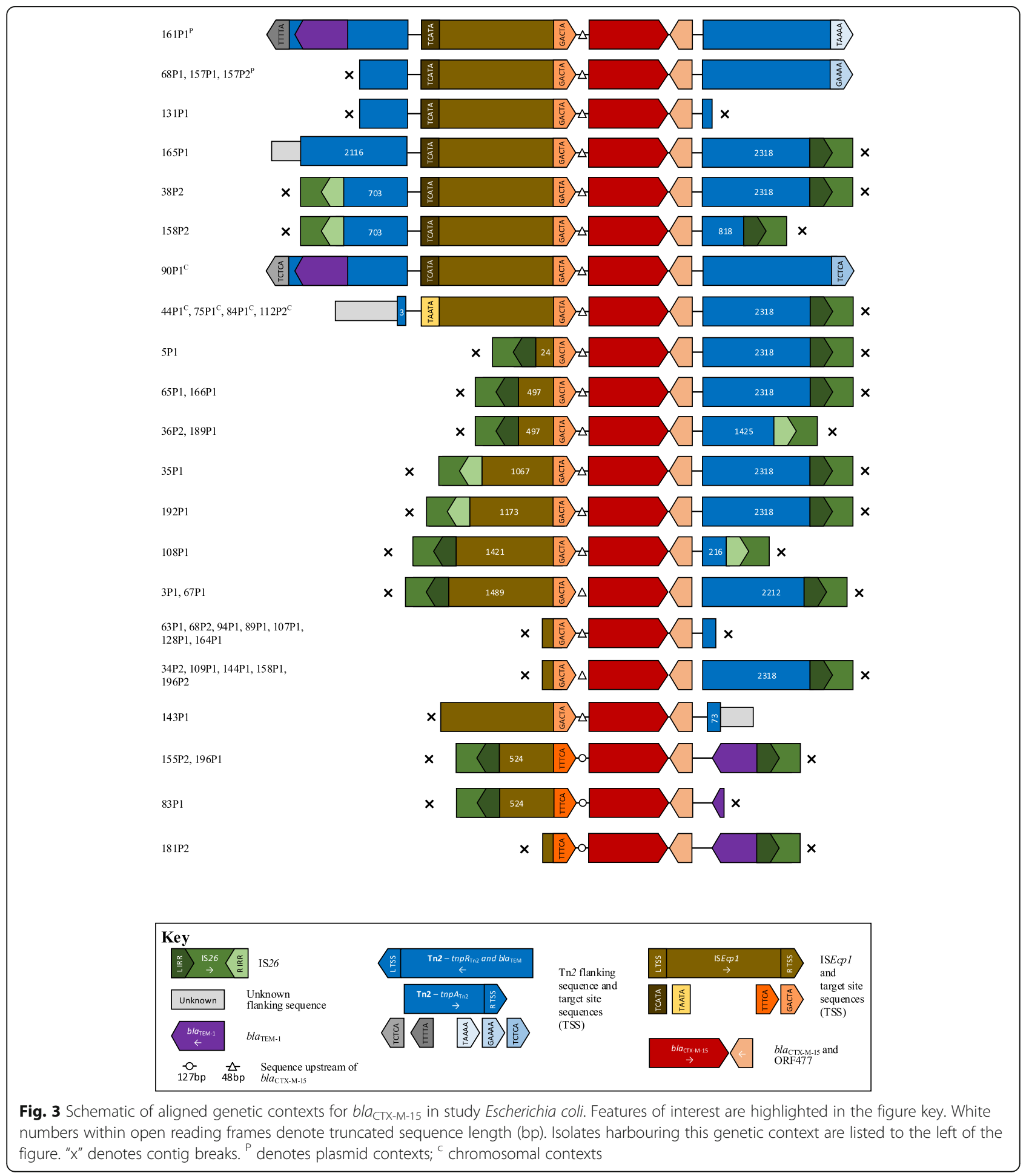


TTTTA-TAAAA target site sequences [TSSs] respectively) (Fig. 3). Overall, genetic contexts of bla were consistent with integration and mobilisation of ISEcp1-bla $a_{\mathrm{CTX}-\mathrm{M}-15}$ within a Tn2 element, as previously described [27], with subsequent rearrangement events facilitated by IS26 and perhaps other ISs [26] (Additional file 2: Table S3).

For the 24 E. coli harbouring $b l a_{\mathrm{CTX}-\mathrm{M}-55}$, it was chromosomally located in $4(17 \%)$, plasmid in $4(17 \%)$ and unknown in 16 (67\%). One contig contained a truncated

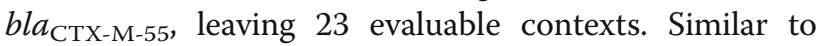
$b l a_{\mathrm{CTX}-\mathrm{M}-15}$, it was invariably associated with ISEcp1 upstream of $b l a_{\mathrm{CTX}-\mathrm{M}-55}$ (Fig. 4), which was often incomplete, representing at least 3 different IS26-associated
ISEcp1 disruption events (Table 3). Intact ISEcp1 were flanked by variable lengths of $\mathrm{Tn} 2$ sequence, apart from $120 \mathrm{P} 1$ where the contig was truncated immediately at the $5^{\prime}$ end of ISEcp1. One isolate (2P1) had the same $b l a_{\mathrm{CTX}-\mathrm{M}} / \mathrm{Tn} 2$ unit as for $b l a_{\mathrm{CTX}-\mathrm{M}-15}$ (but with TACT C-TAAAA), consistent with the evolution of $b l a_{\text {CTX-M-55 }}$ from $b l a_{\mathrm{CTX}-\mathrm{M}-15}$ (1 SNV difference) within this unit (Figs. 3 and 4).

For the 15 E. coli harbouring bla $_{\mathrm{CTX-M-14}}$, it was chromosomally located in $2(13 \%)$ cases, plasmid-associated in $5(33 \%)$, and unknown in 8 (53\%). Again, it was invariably associated with ISEcp1, but more often complete and with different mechanisms of disruption (2 ISVsa5-like sequence, one IS1S R IRR). All cases had an IS903 element

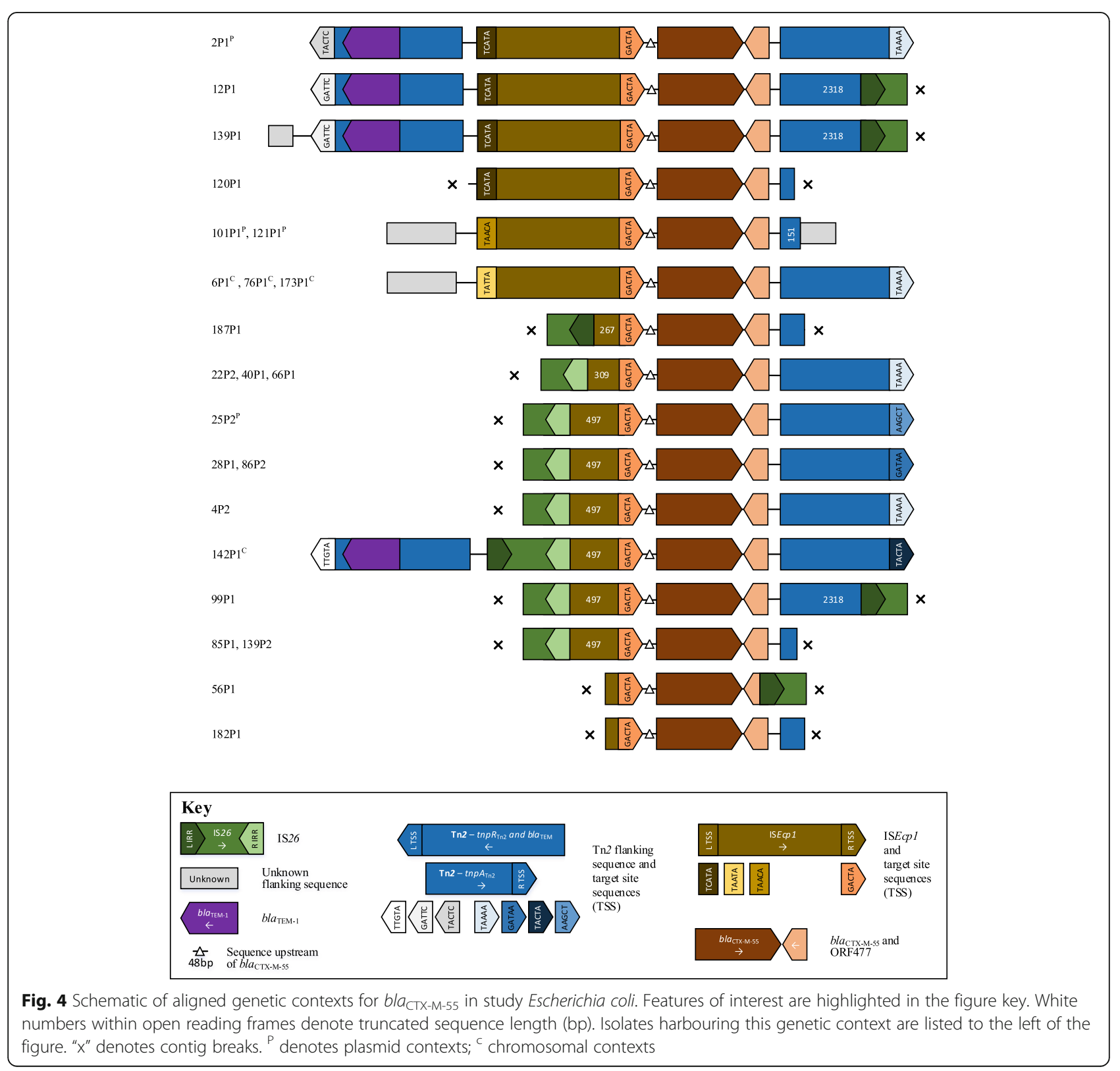


at the $3^{\prime}$ end of bla $a_{\mathrm{CTX}-\mathrm{M}-14}$; this had been disrupted in 6 cases, with additional contig breaks in 5 cases (Fig. 5). Two of three E. coli bla $a_{\mathrm{CTX}-\mathrm{M}-24}$ contexts were chromosomal, with flanking contexts similar to $b l a_{\mathrm{CTX}-\mathrm{M}-14}$ (Additional file 3: Figure S1). In the $12 b l a_{\mathrm{CTX}-\mathrm{M}-27}$ cases, the ISEcp 1 element had been disrupted by an IS26 L IRR in all contexts, at 149, 192, 208 and $388 \mathrm{bp}$, but the wider genetic context of this structure was indeterminable in all cases (Additional file 4: Figure S2).

Overall, bla $a_{\text {CTX-M }}$ was chromosomal in 13/92 cases (14\%; $13 / 25$ [52\%] cases where plasmid versus chromosomal location could be assessed), suggesting that CTX-M genes may be incorporated chromosomally and indiscriminately in significant numbers of colonising $E$. coli, with possible implications for their stable propagation within the wider E. coli population.
For K. pneumoniae, 12 isolates harboured $b l a_{\mathrm{CTX}-\mathrm{M}-15}$, in a plasmid-associated context in $9 / 12$ cases, and an unknown context in 3/12 cases. Three isolates harboured a complete $b l a_{\mathrm{CTX}-\mathrm{M}-15} / \mathrm{Tn} 2$ complex with GTTAA-GTTAA TSS, most consistent with a direct transposition of this element into a plasmid context. In the other isolates,

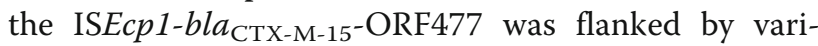
able stretches of $\operatorname{Tn} 2$-associated sequence identical to that found in the $E$. coli isolates, and similarly truncated either as a result of contig breaks, or by IS26 inverted repeats, consistent with between species and within species mobilisation (Additional file 5: Figure S3).

Four $K$. pneumoniae isolates harboured $b l a_{\mathrm{CTX}-\mathrm{M}-9}$ group genes; two of these $\left(b l a_{\mathrm{CTX}-\mathrm{M}-14}\right)$ shared the same ISEcp1 (Fig. 5) and $\sim 18 \mathrm{~kb}$ upstream flanking plasmid sequence; and two $\left(b l a_{\mathrm{CTX}-\mathrm{M}-27}\right)$ an ISEcp1

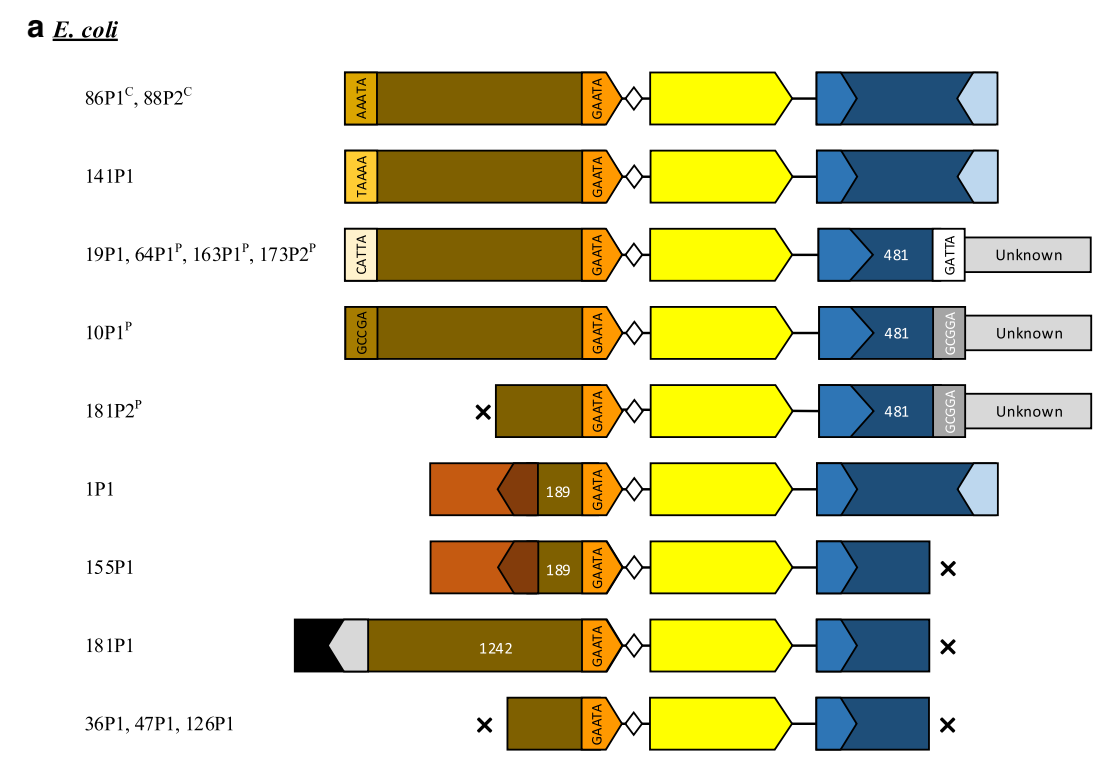

b $\underline{\text { K. pneumoniae }}$

$178 \mathrm{~B} 2^{\mathrm{P}}$

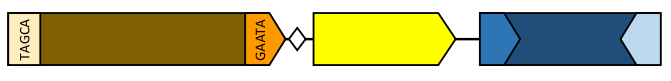

$20 \mathrm{~B} 1^{\mathrm{p}}$
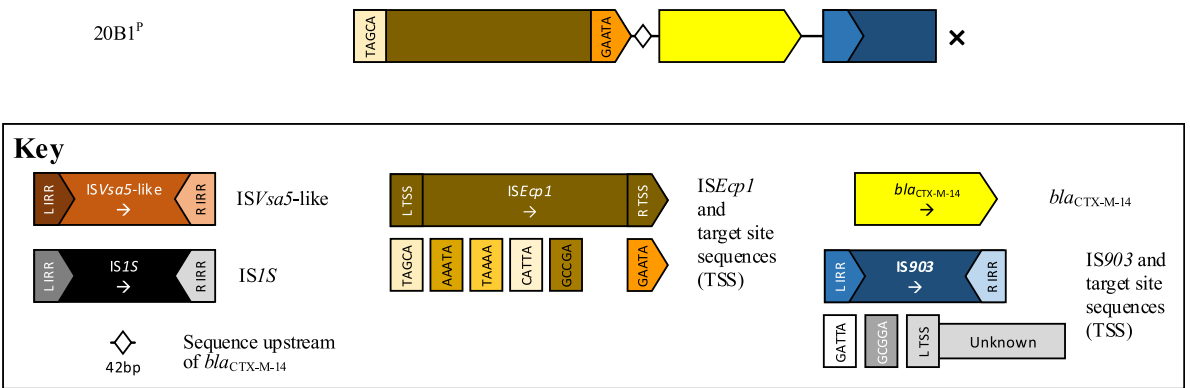

Fig. 5 Schematic of aligned genetic contexts for bla CTX-M-14 $_{1}$ in study Escherichia coli (a) and Klebsiella pneumoniae (b). Features of interest are highlighted in the figure key. White numbers within open reading frames denote truncated sequence length (bp). Isolates harbouring this genetic context are listed to the left of the figure. " $x$ " denotes contig breaks. ${ }^{P}$ denotes plasmid contexts; ${ }^{C}$ chromosomal contexts 
element truncated at position 1499 by an IS26 L IRR (Additional file 4: Figure S2).

\section{Discussion}

We observed significant gastrointestinal carriage prevalence of both ESC-R-EC and ESC-R-KP in Cambodian children sampled in 2012; approximately one in twelve children was co-colonised with ESC-R strains of both species. A wide diversity of ESC-R strain types was observed, including several genotypes categorised as "high risk" clones, such as E. coli STs $38,405,131,354$ and 648 [15]. The predominant ESC-R genotypic mechanism was bla $a_{\text {СТХ-M }}$, with the major allelic variants being those widely described elsewhere in Asia (Group 1: bla $a_{\mathrm{CTX}-\mathrm{M}-15,-55}$, Group 9: bla $a_{\mathrm{CTX}-\mathrm{M}-14,-24,-27}$ ). Approximately one-third of the Cambodian population is $<18$ years old, so this group may be acting as a significant reservoir for the spread of antimicrobial resistant organisms.

We did not identify any carbapenem-resistant isolates using our imipenem-based screening method; however, two (1\%) individuals were colonised with transmissible carbapenemase genes identified on sequencing of cultured isolates. These isolates were phenotypically susceptible or intermediately-susceptible to imipenem, which has since been shown to be a less sensitive indicator of carbapenemase - particularly $b l a_{\text {OXA- } 48 \text { - presence, and }}$ we may therefore have been underestimating the prevalence of these genes [16]. Nevertheless, our results are consistent with other Cambodian datasets, including an earlier study (2007-2010) where no carbapenemase genes were identified in 183 Enterobacteriaceae blood culture isolates by means of PCR and a more recent study (20132014) where only 2 of $289(0.7 \%)$ hospitalised neonates were found to harbour imipenem-resistant isolates $[9,13]$. This could be explained by a much lower antibiotic selection pressure resulting from poor local availability of carbapenems compared with other neighbouring countries such as Thailand at the time of the study. Of note, the bla $a_{\text {OXA-48 }}-E$. coli isolate from this study was isolated from an outpatient without any known chronic health problems, suggesting there may be some carriage of carbapenem-resistant isolates in the community (or that we missed a healthcare exposure for this individual). Repeat assessment of the extent of carbapenemresistant EC/KP in both community and hospitalised individuals in Cambodia is warranted.

Independent risk factors for colonisation by ESC$\mathrm{R}$-EC/KP included inpatient status, consistent with transmission within hospital, and/or selection of these organisms from low-level carriage by the use of antibiotics on admission given the high burden of infectious diseases in this region. Infection control in resource-limited settings remains challenging, and despite improvements within the study hospital [17], recent longitudinal surveillance within the neonatal care unit identified high rates of import of ESC-R-KP (62\% colonised on admission) as well as nosocomial acquisition (23\%) [13]. Inpatient acquisition of ESC-R-EC/KP has also been identified as a major problem in other low/middle-income settings [18]. The specific effect of faecal parasites on gut microbiota is not wellstudied, but they are thought to significantly perturb microbial diversity [19]. Parasite infestation may also result in inappropriate antimicrobial use, including antibiotics, perhaps leading to secondary colonization with drug-resistant commensals. The decreased risk associated with school attendance has been observed in a previous study in Spain [20], and may represent a proxy marker for increased socio-economic status, and parental levels of education, which were not evaluated here, but may translate into better awareness of appropriate antibiotic use $[21,22]$. The decreased risk associated with male gender is unexplained; but independent associations for ESBL-EC/ KP colonization have been described for both genders in previous studies [18, 23, 24].

Of particular importance was the high prevalence of chromosomal integration of $b l a_{\mathrm{CTX}-\mathrm{M}}$ in $E$. coli in this study ( $>14 \%$ ), perhaps contributing to the stable propagation of this resistance gene family within certain strains. Whilst the previously reported chromosomal integration of bla СТX-M in Spanish K. pneumoniae isolates was not observed in our study, this could not be excluded for three isolates in which the $b l a_{\text {CTX-M }}$ genetic location (i.e. either plasmid or chromosomal) remained indeterminate due to the limitations of the genetic assemblies [25]. In addition, despite the limitations of short-read assemblies, the genetic contexts of $b l a_{\text {CTX-M }}$ suggested high levels of genetic plasticity in flanking structures, and significant associations with IS26 for $b l a_{\mathrm{CTX}-\mathrm{M}-15}, b l a_{\mathrm{CTX}-\mathrm{M}-55}$, and $b l a_{\mathrm{CTX}-\mathrm{M}-27}$. IS26 has been previously hypothesised to facilitate the mobility of bla $a_{\mathrm{CTX}-\mathrm{M}}$ and genetic rearrangement of resistance gene plasmids, and is likely contributing to the dissemination of these resistance genes within the human gastrointestinal reservoir [26-28].

This study has several limitations. Our survey dates from 2012, and the epidemiology of ESC-R EC/KP carriage may have changed in the intervening timeframe. We only included up to three bacterial colonies per faecal sample, likely resulting in significant under-estimation of the diversity present at the population level [14]. Also, storage conditions for faecal samples may have impacted on the isolates that were cultured. Short-read sequencing resulted in limited information regarding the wider genetic context of important resistance genes conferring ESC-R; nevertheless, we were still able to ascertain that the genetic contexts of these resistance genes are extremely diverse. Our outpatient study population may not 
be truly representative of healthy children in the community, given that these were individuals that had presented to the outpatient department for some form of medical review. Lack of more detailed information on some potential risk factors meant we were unable to fully assess the specific mechanisms promoting ESC-R EC/KP colonisation. Further work characterising the role of healthcare admissions, socio-economic factors and intestinal parasites on the acquisition and long-term carriage dynamics of these strains would be valuable. In addition, our sample size was too small and sparse to investigate geographical clustering of strain types, and to investigate specific risk factors for colonisation with common strain types or resistance gene alleles. Despite these limitations, our data are important as they represent the largest molecular epidemiological study of gastrointestinal ESC-R-EC/KP colonisation in Cambodia and form a useful benchmark for future studies.

\section{Conclusion}

This study adds to the growing body of literature demonstrating widespread gastrointestinal colonisation with ESC-R-EC and ESC-R KP in Southeast Asia [8], and showing that exposure to this reservoir may in turn act as a source for the wider, global transfer of these strains [29]. The genetic contexts of important resistance genes are highly mosaic, consistent with rapid exchange of resistance genes within and between bacterial hosts. Significant levels of chromosomal integration of the most important ESC-R gene family, bla $a_{\mathrm{CTX}-\mathrm{M}}$, were also observed, and may result in these genes being stably maintained and propagated in one of the most common community-associated pathogens, namely $E$. coli. Our observations are alarming and, in the context of widespread, unregulated and often inappropriate antibiotic use, as seen in Cambodia, these selection pressures are likely to further facilitate the dissemination of AMR genes.

\section{Methods}

\section{Patients and setting}

Faecal samples were obtained from a consecutive subset of children/adolescents ( $<16$ years) who had been enrolled in a prospective study that aimed to identify the prevalence of intestinal parasites in children/adolescents attending Angkor Hospital for Children in Siem Reap, Cambodia, from 3rd April 2012 to 29th June 2012, as described previously [30]. Informed consent was obtained by explaining the study to children/adolescents and their caregivers, and confirmed by the caregiver's signature or a witnessed thumbprint if they were illiterate.

\section{Microbiological methods}

Samples were frozen at $-80{ }^{\circ} \mathrm{C}$ as aliquots homogenised in $0.9 \%$ sterile saline with $10 \%$ glycerol within an hour of receipt in the laboratory. For this study, faecal samples were thawed, and aliquots diluted 1:10 in saline and incubated for $16 \mathrm{~h}$ at $37^{\circ} \mathrm{C}$ on Orientation CHROMagar (BD, Oxford, United Kingdom) with $10 \mu \mathrm{g}$ cefpodoxime and $10 \mu \mathrm{g}$ imipenem discs (Oxoid, Basingstoke, United Kingdom). For each faecal sample, up to three pink and/or dark blue colonies with different colonial morphotypes that grew within the cefpodoxime zone of inhibition (presumed ESC-R-EC and ESC-R-KP respectively) were selected for further analysis. Each selected colony was tested using the British Society of Antimicrobial Chemotherapy (BSAC) combination disc method to identify whether cefpodoxime (ESC) resistance was mediated via ESBLs (Class A: cefpodoximeresistant, and cefpodoxime+clavulanic acid-sensitive) or via non-ESBL mechanisms (e.g. Class C AmpC beta-lactamases: cefpodoxime-resistant, and cefpodoxime+clavulanic acid-resistant) [31]. All identified ESC$\mathrm{R}$ colonies were stored frozen at $-80{ }^{\circ} \mathrm{C}$ in nutrient broth with $10 \%$ glycerol. Carbapenem susceptibility testing was performed via BD Phoenix automated susceptibility testing (microbroth dilution method; Becton Dickinson, Franklin Lakes, NJ, USA).

\section{Whole genome sequencing and sequence data processing}

DNA was extracted from sub-cultured ESC-R isolates using a commercial kit (Fujifilm Quickgene, Japan) with an additional mechanical lysis step (Fastprep MP Biomedicals, USA). All isolates were sequenced using the Illumina HiSeq 2500, generating $150 \mathrm{bp}$ paired-end reads. Sequence data have been deposited in GenBank (project accession: PRJNA391054).

To identify single nucleotide variants (SNVs) reads were mapped to species-appropriate reference genomes (E. coli CFT073 [GenBank: AE014075.1] and $K$. pneumoniae MGH78578 [GenBank: CP000647.1]), and variants called as described previously [32]. Alignments of variable sites were padded to the length of the reference genome using bases with the same \%GC content as that observed within each dataset. Bootstrapped, maximum-likelihood phylogenies were reconstructed for each species using RaxML version 7.7.6 [33], using a generalised time-reversible model and four categories of rate heterogeneity (./RAxML-7.7.6/ raxmlHPC-PTHREADS-SSE3 -f a $-\mathrm{s}<$ input_alignment.phy > -m GTRGAMMA -p 12345 -c 4 -× 12,345 -\# 100 -n $<$ output_raxml_rapid_bootstrap $>$ ). Phylogenies have been deposited as projects in MicroReact to enable an interactive assessment of geographic distribution of genotypes ( $E$. coli: https://microreact.org/project/By8bf5ajg; K. pneumoniae: https://microreact.org/project/Hy_yQcaog [34]. 
Contigs were assembled using Velvet/VelvetOptimiser (hash value range: 75-149) [35, 36]. In silico MLST was determined by BLASTn [37] matches (100\% match) to the Achtman/Pasteur MLST schemes for E. coli and $K$. pneumoniae [38, 39], and supported correct species identification. The presence/absence of resistance genes was determined using BLASTn and an in-house curated resistance gene database of over 60 gene families [40]. Genes were considered present if a blast match of $\geq 80 \%$ of the query sequence was identified at $\geq 80 \%$ sequence identity using the de novo assemblies as blast databases. Ambler class genotype was class A if $b l a_{\mathrm{CTX}-\mathrm{M}}, b l a_{\mathrm{SHV}}$ and/or $b l a_{\mathrm{VEB}}$ were present, and/or class $\mathrm{C}$ if $b l a_{\mathrm{CMY}-2}$, $b l a_{\mathrm{DHA}}$ and $b l a_{\mathrm{ACT}}$-like genes were present. Where patient faecal samples yielded $\geq 2$ strains, all resistance genes were treated as a single entity within the individual's profile.

The genetic context of $b l a_{\text {СтX-M }}$ was examined by extracting the contigs containing these genes, and annotating these using PROKKA [41], combined with BLASTn and manual annotation with reference to mobile genetic elements in the ISFinder database [42]. Gene locations were characterised as "chromosomal" if other annotations on the contig were only found in chromosomal contexts in the top 20 BLASTn hits when the contig was compared with bacterial sequences available in GenBank (using default parameters); "plasmid" if the other annotations matched only plasmid sequences; or unknown if these conditions were not met e.g. the assembled contigs were too short to verify this.

\section{Epidemiological analyses}

Information regarding putative socio-demographic risk factors for ESC-R EC/KP colonisation (collected on a standardised form) included details on: gender, age, hospitalisation status, residence in Siem Reap province versus elsewhere, water source (river, rain, well, bottled, piped, boiled), domestic animals (cats, dogs, birds), livestock (chickens, ducks, pigs, cows or water buffalo), toilet availability, malnutrition, co-morbidities, presence/ absence of diarrhoea, presence/absence of parasites (assessed within [30]), soap usage for hand-washing and school attendance. No details regarding antibiotic consumption were ascertained within the study, but previous work locally has shown that individuals are often ill-informed about the nature of any medications used and that $32 \%$ of outpatient attendees have evidence of urinary antimicrobial activity [43].

\section{Statistical analyses}

Independent risk factors for carriage were identified from a multivariable, stepwise, logistic regression model based on complete cases and initially including all factors (backwards elimination using exit $p<0.1$ to reduce over-fitting). A final multivariable logistic model was then fitted including all cases for which complete information was available for the retained risk factors. Statistical analyses were performed using STATA version 14. (StataCorp, College Station, USA).

\section{Additional files}

\begin{abstract}
Additional file 1: Table S1. Sequence type distribution of $E$. coli isolates obtained in this study. Table S2. Sequence type distribution of $K$. pneumoniae isolates obtained in this study. (DOCX $17 \mathrm{~kb}$ )
\end{abstract}

Additional file 2: Table S3. Detail of genetic contexts for bla $a_{C T X-M}$ in sequenced isolates. (XLSX $22 \mathrm{~kb}$ )

Additional file 3: Figure S1. Schematic of aligned genetic contexts for bla $a_{\mathrm{CTX}-\mathrm{M}-24}$ in study Escherichia coli. Features of interest are highlighted in the figure key. White numbers within open reading frames denote truncated sequence length (bp). Isolates harbouring this genetic context are listed to the left of the figure. " $x$ " denotes contig breaks. ${ }^{P}$ denotes plasmid contexts; ${ }^{c}$ chromosomal contexts. (PDF $405 \mathrm{~kb}$ )

Additional file 4: Figure S2. Schematic of aligned genetic contexts for bla $a_{C \mathrm{TX}-\mathrm{M}-27}$ in study Escherichia coli and Klebsiella pneumoniae. Features of interest are highlighted in the figure key. White numbers within open reading frames denote truncated sequence length (bp). Isolates harbouring this genetic context are listed to the left of the figure. " $x$ " denotes contig breaks. ${ }^{\mathrm{P}}$ denotes plasmid contexts; ${ }^{\mathrm{C}}$ chromosomal contexts. (PDF $410 \mathrm{~kb}$ )

Additional file 5: Figure S3. Schematic of aligned genetic contexts for bla $a_{\mathrm{CTX}-\mathrm{M}-15}$ in study Klebsiella pneumoniae. Features of interest are highlighted in the figure key. White numbers within open reading frames denote truncated sequence length (bp). Isolates harbouring this genetic context are listed to the left of the figure. " $x$ " denotes contig breaks. ${ }^{P}$ denotes plasmid contexts; ${ }^{c}$ chromosomal contexts. (PDF $410 \mathrm{~kb}$ )

\section{Acknowledgements}

The authors wish to thank the staff and patients at Angkor Hospital for Children, Siem Reap, Cambodia, and members of the Modernising Medical Microbiology Informatics Group, and Hannah Kerridge, of the John Radcliffe Hospital Microbiology Laboratory, Oxford, UK, for her assistance with susceptibility phenotyping of isolates.

\section{Funding}

This work was supported by the National Institute for Health Research (NIHR) Oxford Biomedical Research Center (BRC). JJvA was funded through a National Institute for Health Research (NIHR) Academic Clinical Fellowship. NS is currently funded through a PHE/ University of Oxford Clinical Lectureship; the sequencing work was also partly funded through a previous Wellcome Trust Doctoral Research Fellowship (\#099423/Z/12/Z). TEAP and DWC are NIHR Senior Investigators. The funders had no role in study design, data collection and interpretation, or the decision to submit the work for publication. The views expressed are those of the author(s) and not necessarily those of the NHS, the NIHR or the Department of Health.

\section{Availability of data and materials}

The data have been deposited as part of BioProject accession number PRJNA391054 in the NCBI BioProject database (https://www.ncbi.nlm. nih.gov/bioproject/).

\section{Authors' contributions}

This project was conceived and designed by NS, TEAP, NPJD, DWC, ASW, CEM and JJVA. CEM, CMP, PT, NP, SM, and KS collected patient data and faecal samples. JJVA and NS conducted faecal screening for ESC-R-EC/KP in addition to preparation of isolates for whole genome sequencing. NS, TD, AG and AES developed and executed bioinformatics analysis of the sequence data. NS, JJVA and ASW performed the statistical analysis. NS and JJVA interpreted 
the patient and bioinformatics data sets, and wrote the manuscript. All the authors have read, revised and approved the final manuscript.

\section{Ethics approval and consent to participate}

The study was approved by the Institutional Review Board (IRB), Angkor Hospital for Children, and the Oxford Tropical Research Ethics Committee (OXTREC 12-12). Caregivers of all included participants gave informed consent for their child to participate in the intestinal parasite survey, and for the samples to be used more widely in additional studies approved by the IRB. For patients who did not provide consent, their samples were excluded from the study.

\section{Consent for publication}

Not applicable.

\section{Competing interests}

The authors declare that they have no competing interests.

\section{Publisher's Note}

Springer Nature remains neutral with regard to jurisdictional claims in published maps and institutional affiliations.

\section{Author details}

${ }^{1}$ Nuffield Department of Clinical Medicine and the National Institute for Health Research Oxford Biomedical Research Centre (NIHR-OxBRC), University of Oxford, Oxford, UK. ${ }^{2}$ Department of Clinical Infection, Microbiology and Immunology, Institute of Infection and Global Health, University of Liverpool, The Ronald Ross Building, 8 West Derby Street, Liverpool L69 7BE, UK. ${ }^{3}$ Clinical Sciences, Liverpool School of Tropical Medicine, Liverpool, UK. ${ }^{4}$ Cambodia-Oxford Medical Research Unit, Angkor Hospital for Children, Siem Reap, Cambodia. ${ }^{5}$ Centre for Tropical Medicine and Global Health, Nuffield Department of Medicine, University of Oxford, Oxford, UK. ${ }^{6}$ Angkor Hospital for Children, Siem Reap, Cambodia. ${ }^{7}$ Mahidol-Oxford Tropical Medicine Research Unit, Faculty of Tropical Medicine, Mahidol University, Bangkok, Thailand. ${ }^{8}$ Department of Microbiology/Infectious Diseases, John Radcliffe Hospital, Headley Way, Headington OX3 9DU, UK.

Received: 27 December 2017 Accepted: 4 March 2019

Published online: 12 March 2019

\section{References}

1. Carlet J. The gut is the epicentre of antibiotic resistance. Antimicrob Resist Infect Control. 2012;1(1):39.

2. Selden R, Lee S, Wang WL, Bennett JV, Eickhoff TC. Nosocomial klebsiella infections: intestinal colonization as a reservoir. Ann Intern Med. 1971;74(5): 657-64.

3. Pitout JD, Laupland KB. Extended-spectrum beta-lactamase-producing Enterobacteriaceae: an emerging public-health concern. Lancet Infect Dis. 2008;8(3):159-66.

4. Rottier WC, Ammerlaan HS, Bonten MJ. Effects of confounders and intermediates on the association of bacteraemia caused by extendedspectrum beta-lactamase-producing Enterobacteriaceae and patient outcome: a meta-analysis. J Antimicrob Chemother. 2012;67(6):1311-20.

5. Schwaber MJ, Navon-Venezia S, Kaye KS, Ben-Ami R, Schwartz D, Carmeli Y. Clinical and economic impact of bacteremia with extended- spectrum-betalactamase-producing Enterobacteriaceae. Antimicrob Agents Chemother. 2006;50(4):1257-62.

6. Luvsansharav UO, Hirai I, Nakata A, Imura K, Yamauchi K, Niki M, Komalamisra C, Kusolsuk T, Yamamoto Y. Prevalence of and risk factors associated with faecal carriage of CTX-M beta-lactamase-producing Enterobacteriaceae in rural Thai communities. J Antimicrob Chemother. 2012;67(7):1769-74.

7. Stoesser N, Crook DW, Moore CE, Phetsouvanh R, Chansamouth V, Newton PN, Jones N. Characteristics of CTX-M ESBL-producing Escherichia coli isolates from the Lao People's Democratic Republic, 2004-09. J Antimicrob Chemother. 2012;67(1):240-2.

8. Woerther PL, Burdet C, Chachaty E, Andremont A. Trends in human fecal carriage of extended-spectrum beta-lactamases in the community: toward the globalization of CTX-M. Clin Microbiol Rev. 2013;26(4):744-58.

9. Vlieghe ER, Huang TD, Phe T, Bogaerts P, Berhin C, De Smet B, Peetermans WE, Jacobs JA, Glupczynski Y. Prevalence and distribution of beta-lactamase coding genes in third-generation cephalosporin-resistant Enterobacteriaceae from bloodstream infections in Cambodia. Eur J Clin Microbiol Infect Dis. 2015;34(6):1223-9.

10. Ruppe E, Hem S, Lath S, Gautier V, Ariey F, Sarthou JL, Monchy D, Arlet G. CTX-M beta-lactamases in Escherichia coli from community-acquired urinary tract infections, Cambodia. Emerg Infect Dis. 2009;15(5):741-8.

11. Moore CE, Sona S, Poda S, Putchhat H, Kumar V, Sopheary S, Stoesser N, Bousfield R, Day N, Parry CM. Antimicrobial susceptibility of uropathogens isolated from Cambodian children. Paediatr Int Child Health. 2016:1-5.

12. Caron Y, Chheang R, Puthea N, Soda M, Boyer S, Tarantola A, Kerleguer A. Beta-lactam resistance among Enterobacteriaceae in Cambodia: the fouryear itch. Int J Infect Dis. 2017;66:74-9.

13. Turner P, Pol S, Soeng S, Sar P, Neou L, Chea P, Day NP, Cooper BS, Turner C. High prevalence of antimicrobial-resistant gram-negative colonization in hospitalized Cambodian infants. Pediatr Infect Dis J. 2016;35(8):856-61.

14. Stoesser N, Sheppard AE, Moore CE, Golubchik T, Parry CM, Nget P, Saroeun M, Day NP, Giess A, Johnson JR, et al. Extensive within-host diversity in Fecally carried extended-Spectrum-Beta-lactamase-producing Escherichia coli isolates: implications for transmission analyses. J Clin Microbiol. 2015; 53(7):2122-31

15. Woodford N, Turton JF, Livermore DM. Multiresistant gram-negative bacteria: the role of high-risk clones in the dissemination of antibiotic resistance. FEMS Microbiol Rev. 2011;35(5):736-55.

16. Karlowsky JA, Lob SH, Kazmierczak KM, Badal RE, Young K, Motyl MR, Sahm DF. In vitro activity of imipenem against Carbapenemase-positive Enterobacteriaceae isolates collected by the SMART global surveillance program from 2008 to 2014. J Clin Microbiol. 2017;55(6):1638-49.

17. Stoesser N, Emary K, Soklin S, Peng An K, Sophal S, Chhomrath S, Day NP, Limmathurotsakul $D$, Nget $P$, Pangnarith $Y$, et al. The value of intermittent point-prevalence surveys of healthcare-associated infections for evaluating infection control interventions at Angkor Hospital for Children, Siem Reap, Cambodia. Trans R Soc Trop Med Hyg. 2013;107(4):248-53.

18. Kurz MS, Bayingana C, Ndoli JM, Sendegeya A, Durst A, Pfuller R, Gahutu JB, Mockenhaupt FP. Intense pre-admission carriage and further acquisition of ESBL-producing Enterobacteriaceae among patients and their caregivers in a tertiary hospital in Rwanda. Tropical Med Int Health. 2017;22(2):210-20.

19. Lee SC, Tang MS, Lim YA, Choy SH, Kurtz ZD, Cox LM, Gundra UM, Cho I, Bonneau R, Blaser MJ, et al. Helminth colonization is associated with increased diversity of the gut microbiota. PLoS Negl Trop Dis. 2014;8(5):e2880.

20. Fernandez-Reyes M, Vicente D, Gomariz M, Esnal O, Landa J, Onate E, PerezTrallero E. High rate of fecal carriage of extended-spectrum-beta-lactamaseproducing Escherichia coli in healthy children in Gipuzkoa, northern Spain. Antimicrob Agents Chemother. 2014;58(3):1822-4.

21. Ling OA, Hassali MA, Al-Haddad MS, Syed Sulaiman SA, Shafie AA, Awaisu A Public knowledge and attitudes towards antibiotic usage: a cross-sectional study among the general public in the state of Penang, Malaysia. J Infect Dev Ctries. 2011;5(5):338-47.

22. Gebeyehu E, Bantie L, Azage M. Inappropriate use of antibiotics and its associated factors among urban and rural communities of Bahir Dar City Administration, Northwest Ethiopia. PLoS One. 2015;10(9):e0138179.

23. Ben-Ami R, Rodriguez-Bano J, Arslan H, Pitout JD, Quentin C, Calbo ES, Azap OK, Arpin C, Pascual A, Livermore DM, et al. A multinational survey of risk factors for infection with extended-spectrum beta-lactamase-producing enterobacteriaceae in nonhospitalized patients. Clin Infect Dis. 2009;49(5):682-90.

24. Pena C, Gudiol C, Tubau F, Saballs M, Pujol M, Dominguez MA, Calatayud L, Ariza J, Gudiol F. Risk-factors for acquisition of extended-spectrum betalactamase-producing Escherichia coli among hospitalised patients. Clin Microbiol Infect. 2006;12(3):279-84.

25. Coelho A, Gonzalez-Lopez JJ, Miro E, Alonso-Tarres C, Mirelis B, Larrosa MN, Bartolome RM, Andreu A, Navarro F, Johnson JR, et al. Characterisation of the CTX-M-15-encoding gene in Klebsiella pneumoniae strains from the Barcelona metropolitan area: plasmid diversity and chromosomal integration. Int J Antimicrob Agents. 2010;36(1):73-8.

26. He S, Hickman AB, Varani AM, Siguier P, Chandler M, Dekker JP, Dyda F. Insertion sequence IS26 reorganizes plasmids in clinically isolated multidrugresistant bacteria by replicative transposition. MBio. 2015;6(3):e00762.

27. Partridge SR, Zong Z, Iredell JR. Recombination in IS26 and Tn2 in the evolution of multiresistance regions carrying blaCTX-M-15 on conjugative IncF plasmids from Escherichia coli. Antimicrob Agents Chemother. 2011; 55(11):4971-8 
28. Stoesser N, Sheppard AE, Pankhurst L, De Maio N, Moore CE, Sebra R, Turner P, Anson LW, Kasarskis A, Batty EM, et al. Evolutionary history of the global emergence of the Escherichia coli epidemic clone ST131. MBio. 2016;7(2):e02162.

29. Arcilla MS, van Hattem JM, Haverkate MR, Bootsma MC, van Genderen PJ, Goorhuis A, Grobusch MP, Lashof AM, Molhoek N, Schultsz C, et al. Import and spread of extended-spectrum beta-lactamase-producing Enterobacteriaceae by international travellers (COMBAT study): a prospective, multicentre cohort study. Lancet Infect Dis. 2017;17(1):78-85.

30. Moore CE, Nget P, Saroeun M, Kuong S, Chanthou S, Kumar V, Bousfield R, Nader J, Bailey JW, Beeching NJ, et al. Intestinal parasite infections in symptomatic children attending hospital in Siem Reap, Cambodia. PLoS One. 2015;10(5):e0123719.

31. Detection of extended-spectrum beta-lactamases (ESBLs) in E. coli and Klebsiella species [http://bsac.org.uk/wp-content/uploads/2012/02/ Ecoliklebsiella.pdf].

32. Stoesser $\mathrm{N}$, Xayaheuang $\mathrm{S}$, Vongsouvath $\mathrm{M}$, Phommasone $\mathrm{K}$, Elliott I, Del Ojo Elias C, Crook DW, Newton PN, Buisson Y, Lee SJ, et al. Colonization with Enterobacteriaceae producing ESBLs in children attending pre-school childcare facilities in the Lao People's Democratic Republic. J Antimicrob Chemother. 2015;70(6):1893-7.

33. Stamatakis A. RAxML-VI-HPC: maximum likelihood-based phylogenetic analyses with thousands of taxa and mixed models. Bioinformatics. 2006; 22(21):2688-90.

34. Aanensen DM, Feil EJ, Holden MT, Dordel J, Yeats CA, Fedosejev A, Goater R, Castillo-Ramirez S, Corander J, Colijn C, et al. Whole-genome sequencing for routine pathogen surveillance in public health: a population snapshot of invasive Staphylococcus aureus in Europe. MBio. 2016;7(3).

35. Zerbino DR. Using the velvet de novo assembler for short-read sequencing technologies. Curr Protoc Bioinformatics. 2010; Chapter 11:Unit 11.5. https:// www.ncbi.nlm.nih.gov/pubmed/20836074

36. VelvetOptimizer [http://bioinformatics.net.au/software.velvetoptimiser.shtml]

37. Altschul SF, Gish W, Miller W, Myers EW, Lipman DJ. Basic local alignment search tool. J Mol Biol. 1990;215(3):403-10.

38. Diancourt L, Passet V, Verhoef J, Grimont PA, Brisse S. Multilocus sequence typing of Klebsiella pneumoniae nosocomial isolates. J Clin Microbiol. 2005; 43(8):4178-82

39. Wirth T, Falush D, Lan R, Colles F, Mensa P, Wieler LH, Karch H, Reeves PR, Maiden MC, Ochman H, et al. Sex and virulence in Escherichia coli: an evolutionary perspective. Mol Microbiol. 2006;60(5):1136-51.

40. Stoesser N, Batty EM, Eyre DW, Morgan M, Wyllie DH, Del Ojo Elias C, Johnson $J R$, Walker AS, Peto TE, Crook DW. Predicting antimicrobial susceptibilities for Escherichia coli and Klebsiella pneumoniae isolates using whole genomic sequence data. J Antimicrob Chemother. 2013;68(10):2234-44.

41. Seemann T. Prokka: rapid prokaryotic genome annotation. Bioinformatics. 2014:30(14):2068-9.

42. Siguier P, Perochon J, Lestrade L, Mahillon J, Chandler M. ISfinder: the reference Centre for bacterial insertion sequences. Nucleic Acids Res. 2006; 34(Database issue):D32-6.

43. Emary KR, Carter MJ, Pol S, Sona S, Kumar V, Day NP, Parry CM, Moore CE. Urinary antibiotic activity in paediatric patients attending an outpatient department in North-Western Cambodia. Tropical Med Int Health. 2015; 20(1):24-8.

\section{Ready to submit your research? Choose BMC and benefit from:}

- fast, convenient online submission

- thorough peer review by experienced researchers in your field

- rapid publication on acceptance

- support for research data, including large and complex data types

- gold Open Access which fosters wider collaboration and increased citations

- maximum visibility for your research: over $100 \mathrm{M}$ website views per year

At BMC, research is always in progress.

Learn more biomedcentral.com/submissions 